\title{
Effect of foliar spray of zinc, iron and boron on the growth, yield and sensory characters of guava (Psidium guajava L.) Cv. Sardar L-49
}

\author{
M. G. Bhoyar ${ }^{1,3^{*}}$ and M.V. Ramdevputra ${ }^{2}$ \\ ${ }^{1}$ Department of Fruit science, Dr. Yashwant Singh Parmar University of Horticulture and Forestry, Nauni, Solan - \\ 173230 (Himachal Pradesh), INDIA \\ ${ }^{2}$ Polytechnique for Horticulture, Junagadh Agricultural University, Dhari - 365640 (Gujarat), INDIA \\ ${ }^{3}$ Department of Horticulture, Junagadh Agricultural University, Junagadh - 362001 (Gujarat), INDIA \\ *Corresponding author. E-mail: mahesh.bhoyar@gmail.com
}

Received: June 19, 2015; Revised received: February 13, 2016; Accepted: May 2, 2016

\begin{abstract}
The field experiment was carried to evaluate the response to the foliar application of micronutrients viz. zinc, iron and boron in single or in different combinations on guava (Psidium guajava L.) cv. Sardar L-49 for various growth, yield and sensory parameters. From various combinations of micronutrients growth characters were remain uninfluenced. Combination of $0.5 \%$ Zinc sulphate $+0.5 \%$ Ferrus sulphate $+0.3 \%$ Borax significantly influenced fruit per shoot (3.6), overall yield (57.1 kg/tree) and sensory characters like aroma (7.7), taste (8.1), flavour (8.2), texture (7.5) and also overall acceptability (7.9). Application of $0.3 \%$ Borax significantly influenced flowers per shoot (5.3). Minimum fruit drop was recorded with application of $0.5 \%$ Ferrus sulphate $+0.3 \%$ Borax and minimum fruit drop per shoot observed in $0.5 \%$ Zinc sulphate $+0.3 \%$ Borax foliar application. The present study indicated that combined application of micronutrients enhanced fruit set, minimized fruit drop and overall yield. This has resulted in improved sensory characters in the guava fruit. This will lure consumers with appealing fruit that would enable farmers to earn a decent sum of money.
\end{abstract}

Keywords: Boron, Foliar application, iron, micronutrients and Zinc

\section{INTRODUCTION}

Guava being most common yet important fruit crop cultivated all over India. It stood in fourth position in terms of area and production after mango, banana and citrus. It belongs to genus Psidium containing over 150 species. But commercially, Psidium guajava L. exploited more due to its hardy nature and wider adaptability. It is being grown successfully in wide range of soil and climatic conditions, even with less attention. To harness better quality of field produce attention must be given for organized fruit production. Special techniques/ methods must be stressed for enhancing the post-harvest quality of the fruit. Best time for getting quality guava fruits which is supposed to be Mrigbahar as fruit flies are eliminated. In eastern and southern India, the guava tree flowers thrice in a year, i.e. February, June-July and October. The respective bahars, are called "Ambe", "Mrig" and "Hasta" bahar. Among all of these three bahars "Mrigbahar" fruits mature during winter i.e. November-January, which are better in quality, taste and higher vitamin $\mathrm{C}$ content. Micronutrients can be applied to plants by soil and foliar application. Foliar application of micronutrients is more effective than soil application. Zinc is one of the eight essential trace elements or micronutrients for the normal healthy growth and reproduction of crop plants (Keram et al., 2014). However, limited work is done on the use of micronutrients for improving fruit size also, overall fruit quality in India as well as in different parts of the world. The importance of micronutrients in achieving higher yield and better quality of fruit crops has been well recognized in recent time (Anonymous 2013). Keeping this in view the study was undertaken to assess the feasibility of micronutrients on growth, yield an sensory attributes pertaining to guava fruit.

\section{MATERIAL AND METHODS}

Field experiment was carried out at Fruit Research Station (Khengarvav), Department of Horticulture, Junagadh Agricultural University, Junagadh, during Kharif 2011-12. Four years old uniform guava plants spaced at $6 \times 6 \mathrm{~m}$ were selected. The experimental findings were analyzed in Randomized Block Design with eight treatments and which are replicated thrice. Two plants considered as a unit. The details of the treatment composition were as T1 $(0.5 \%$ Zinc sulphate), T2 (0.5\% Ferrussulphate), T3 (0.3\% Borax), T4 $(0.5 \%$ Zinc sulphate $+0.5 \%$ Ferrussulphate $)$, T5 $(0.5 \%$ Zinc sulphate $+0.3 \%$ Borax $)$, T6 $(0.5 \%$ Ferrussulphate $+0.3 \%$ Borax $)$, T7 (0.5\% Zinc sulphate $+0.5 \%$ Ferrussulphate $+0.3 \%$ Borax), T8 (Control). Required quantity of zinc sulphate, ferrous sulphate 
and borax were weighed and dissolved in a small quantity of solvent. Calcium hydroxide and citric acid was added in zinc sulphate and ferrous sulphate solution respectively to avoid scorching effect on the leaves. Spraying was done by Knapsack sprayer. Both the upper and lower sides of the leaves were thoroughly sprayed with fine mist. Spraying was done on clear sunny days. The treatment were imposed at four different stages, i.e. pre bloom, full bloom, fruit set initiation and fruit development. The manures and fertilizers applied in each treatment before flowering in first week of July. Well rotten Farm Yard Manure was applied@25 kg per plant. Nitrogen was applied in the form of urea, Phosphorus in the form of single super phosphate and potash in the form of muriate of potash. Nitrogen, phosphorus and potash were applied each @ $250 \mathrm{~g}$ per plant as a basal dose during July. Second dose of nitrogen@250 g per plant was applied at full bloom stage during second week of October. Irrigation was given at 10 days interval or as per requirement through the season. Because of varying period of flowering, the fruits don't mature and ripe at the same time so, it requires frequent hand picking. The fruits were harvested when the skin of fruit turns light yellow. Randomly selected branch in all direction of tree from each treatment were tagged for various observations. The sensory evaluation was carried out for each sample to estimate the organoleptic quality of ripened fruit as per the method suggested by Ranganna (2000). The organoleptic quality in terms of colour, flavour, taste, texture and overall acceptability was done by a panel of judges comprising of scientific workers. All the judges were conversant with the factors governing the quality of the samples using 10point scale as described. The various growth, yield and sensory quality parameters were subjected to statistical analysis as given by Panse and Sukhatme (1985).

\section{RESULTS AND DISCUSSION}

The experimental results pertaining to various plant growth parameters like plant height, plant spread, no. of shoots per tree and length of shoot revealed that the effect of foliar spray of different micronutrients separately and in combination does not significantly influenced any of the character. .

Flowers per shoot: The results revealed that the effect of foliar spray of different micronutrients alone and in combination significantly influenced the flowers per shoot. The maximum number of flowers (5.3) per shoot was observed in T3 $(0.3 \%$ Borax $)$ due to profuse flowering as boron regulates metabolism involved in translocation of carbohydrates, cell wall development and RNA synthesis which was in agreement with Ram and Bose, 2000.

Fruits per shoot:The results indicate that the number of fruits per shoot influenced significantly by the application of foliar sprays of micronutrients. The maximum number of fruits (3.6) per shoot was observed in T7 $(0.5 \%$ Zinc sulphate $+0.5 \%$ Ferrous sulphate $+0.3 \%$ Borax). All the micronutrients when sprayed in combination involved directly in various physiological processes and enzymatic activities. It seems to have helped to increase the fruits per shoot either by improving pollen germination or by helping the growth of pollen tubes and thus facilitate in timely fertilization before the stigma loses its receptivity or the style becomes non-functional. These findings were in accordance with Bhambota (1962) in citrus, Afria (1999) in pomegranate and Yadav et al. (2013) in peach.

The experimental results pertaining to fruit set per cent revealed that none of the micronutrient singly or in combination does not statistically influence any of the treatment.

Fruit drop (\%): The result indicates that the percentage of fruit drop was reduced due to $\mathrm{FeSO}_{4}$ and borax. The minimum fruit drop was recorded $(53.6 \%)$ in T6 $(0.5 \%$ Ferrous sulphate $+0.3 \%$ Borax). Involvement of B in translocation of starch to fruit resulted into better photosynthesis, greater accumulation of starch in fruits balance of auxin which prevents the abscission and facilitated the ovary to remain attached with the shoot,

Table 1. Effect of foliar sprays of zinc, iron and boron on growth and yield characters of guava (All the values are mean of three replicates.

\begin{tabular}{|c|c|c|c|c|c|c|}
\hline S. $\mathbf{N}$. & Treatments & $\begin{array}{l}\text { Plant } \\
\text { height } \\
\text { (cm) }\end{array}$ & $\begin{array}{l}\text { Plant } \\
\text { spread } \\
\text { (cm) }\end{array}$ & $\begin{array}{l}\text { No. of } \\
\text { shoots per } \\
\text { tree }\end{array}$ & $\begin{array}{l}\text { Length of } \\
\text { shoot } \\
(\mathrm{cm})\end{array}$ & $\begin{array}{l}\text { Fruit yield } \\
\text { (kg/tree) }\end{array}$ \\
\hline$\overline{\mathrm{T}_{1}}$ & $0.5 \%$ Zinc sulphate & 282.5 & 427.3 & 7.0 & 34.2 & 42.9 \\
\hline $\mathrm{T}_{2}$ & $0.5 \%$ Ferrous sulphate & 279.9 & 448.6 & 7.0 & 35.3 & 52.7 \\
\hline $\mathrm{T}_{3}$ & $0.3 \%$ Borax & 279.9 & 448.7 & 7.7 & 33.1 & 46.2 \\
\hline $\mathrm{T}_{4}$ & $0.5 \%$ Zinc sulphate $+0.5 \%$ Ferrous sulphate & 273.8 & 432.3 & 7.0 & 34.1 & 42.5 \\
\hline $\mathrm{T}_{5}$ & $0.5 \%$ Zinc sulphate $+0.3 \%$ Borax & 267.2 & 403.4 & 6.0 & 38.7 & 45.0 \\
\hline $\mathrm{T}_{6}$ & $0.5 \%$ Ferrous sulphate $+0.3 \%$ Borax & 274.8 & 431.8 & 6.0 & 37.3 & 42.0 \\
\hline $\mathrm{T}_{7}$ & $\begin{array}{l}0.5 \% \text { Zinc sulphate }+0.5 \% \text { Ferrous sulphate }+ \\
0.3 \% \text { Borax }\end{array}$ & 295.1 & 468.4 & 8.3 & 45.8 & 57.1 \\
\hline $\mathrm{T}_{8}$ & Control (water spray) & 248.5 & 415.5 & 6.3 & 28.1 & 39.1 \\
\hline \multicolumn{2}{|c|}{ S.Em. \pm} & - & - & - & - & 2.04 \\
\hline \multicolumn{2}{|c|}{ C.D. at $5 \%$} & N. S. & N. S. & N. S. & N. S. & 6.18 \\
\hline \multicolumn{2}{|c|}{ C.V. \% } & - & - & - & - & 7.68 \\
\hline
\end{tabular}


Table 2. Effect of foliar sprays of zinc, iron and boron on floral characters of guava (All the values are mean of three replicates.

\begin{tabular}{|c|c|c|c|c|c|c|c|}
\hline S. $\mathbf{N}$. & Treatments & $\begin{array}{l}\text { Flowers } \\
\text { per shoot }\end{array}$ & $\begin{array}{l}\text { Fruits per } \\
\text { shoot }\end{array}$ & $\begin{array}{l}\text { Fruit set } \\
(\%)\end{array}$ & $\begin{array}{l}\text { Fruit drop } \\
(\%)\end{array}$ & $\begin{array}{l}\text { Fruit } \\
\text { retention/ } \\
\text { shoot }\end{array}$ & $\begin{array}{l}\text { Fruit drop/ } \\
\text { shoot }\end{array}$ \\
\hline $\mathrm{T}_{1}$ & $0.5 \%$ Zinc sulphate & 3.7 & 2.6 & 63.5 & 63.1 & 1.4 & 2.3 \\
\hline $\mathrm{T}_{2}$ & $0.5 \%$ Ferrous sulphate & 4.0 & 2.9 & 64.3 & 54.6 & 1.6 & 2.7 \\
\hline $\mathrm{T}_{3}$ & $0.3 \%$ Borax & 5.3 & 3.1 & 67.3 & 61.6 & 1.8 & 3.5 \\
\hline $\mathrm{T}_{4}$ & $\begin{array}{l}0.5 \% \text { Zinc sulphate }+0.5 \% \\
\text { Ferrous sulphate }\end{array}$ & 3.7 & 2.3 & 63.3 & 64.2 & 1.4 & 2.3 \\
\hline $\mathrm{T}_{5}$ & $\begin{array}{l}0.5 \% \text { Zinc sulphate }+0.3 \% \\
\text { Borax }\end{array}$ & 3.3 & 2.7 & 68.1 & 53.6 & 1.5 & 1.8 \\
\hline $\mathrm{T}_{6}$ & $\begin{array}{l}0.5 \% \text { Ferrous sulphate }+ \\
0.3 \% \text { Borax } \\
0.5 \% \text { Zinc sulphate }+0.5 \%\end{array}$ & 4.0 & 2.8 & 65.3 & 59.3 & 1.5 & 2.5 \\
\hline $\mathrm{T}_{7}$ & $\begin{array}{l}\text { Ferrous sulphate }+0.3 \% \\
\text { Borax }\end{array}$ & 5.0 & 3.6 & 71.1 & 55.2 & 1.8 & 2.8 \\
\hline $\mathrm{T}_{8}$ & Control (water spray) & 2.3 & 1.6 & 64.0 & 57.3 & 1.9 & 3.1 \\
\hline \multicolumn{2}{|c|}{ S.Em. \pm} & 0.18 & 0.10 & - & 2.13 & - & 0.12 \\
\hline \multicolumn{2}{|c|}{ C.D. at $5 \%$} & 0.55 & 0.30 & N.S. & 6.45 & N. S. & 0.35 \\
\hline \multicolumn{2}{|c|}{ C.V. \% } & 7.98 & 6.41 & - & 6.29 & - & 7.66 \\
\hline
\end{tabular}

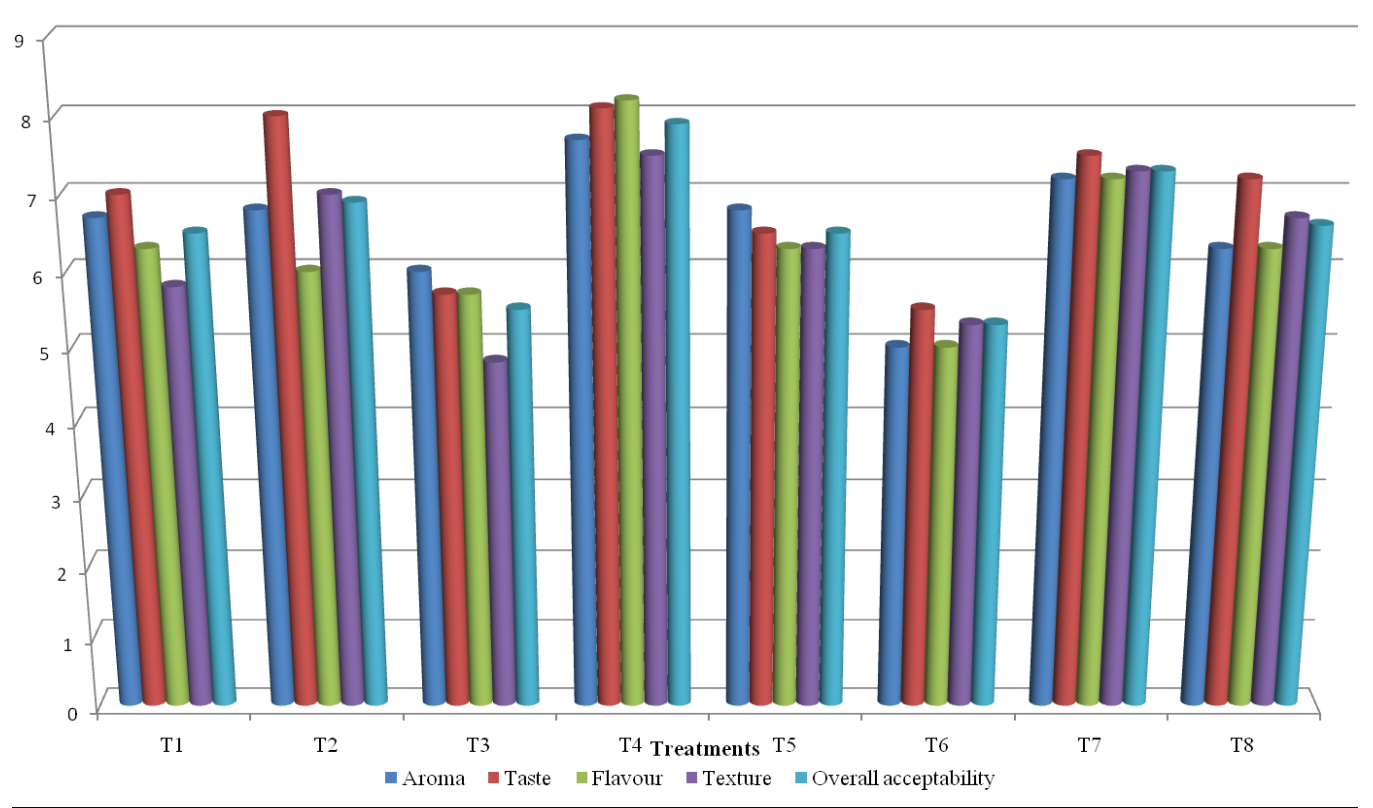

Fig. 1. Effect of foliar sprays of Zinc, Iron and Boron on sensory characters of guava.

resulting in lower fruit drop. The similar results were obtained by Kumar and Shukla (2010) in ber.

The experimental results pertaining to fruit retauntion per shoot revealed that none of the micronutrient singly or in combination does not statistically influence any of the treatment.

Fruit drop/shoot: The result indicates that the fruit drop per shoot was reduced due to $\mathrm{ZnSO}_{4}$ and borax. The minimum fruit drop per shoot was observed (1.8) in $\mathrm{T} 5\left(0.5 \% \mathrm{ZnSO}_{4}+0.3 \%\right.$ Borax $)$. Involvement of $\mathrm{Zn}$ in auxin synthesis and B in translocation of starch to fruit resulted into better photosynthesis; greater accumulation of starch in fruits balance of auxin in plant regulates the fruit drop. The similar results were obtained by Kumar and Shukla (2010) in ber.

Yield parameters: The results revealed that the effect of foliar spray of different micronutrients alone and in combination influenced the overall yield. The application of $\mathrm{T} 7\left(0.5 \% \mathrm{ZnSO}_{4}+0.5 \% \mathrm{FeSO}_{4}+0.3 \%\right.$ Borax $)$ treatment gave the maximum yield $(57.1 \mathrm{~kg})$ per tree as compared to other treatments. The maximum yield was found in $\mathrm{T} 7$ due to cumulative effect of zinc, iron and boron help to increase the fruit size, fruit weight and thereby increase the fruit yield. Similar results were also found by Sarolia et al. (2007) in Guava.

Sensory evaluation: The experimental results for various sensory attributes revealed that, micronutrients affect the overall fruit quality. The sensory evaluation in terms of aroma, taste, flavour, texture and overall acceptability by application various micronutrients by foliar application. The treatment $\mathrm{T} 4\left(0.5 \% \mathrm{Zn} \mathrm{SO}_{4}+\right.$ $0.5 \% \mathrm{FeSO}_{4}$ ) having higher aroma (7.7), taste (8.1), flavour (8.2), texture (7.5) and also overall acceptability (7.9) which are depicted graphically in (chart no. 1). 
An association of zinc with synthesis of auxins in plants played a vital role along with the increase in enzymatic activities. It also acts as a catalyst in oxidation-reduction processes in plants. Guava possesses climacteric phenomenon which triggers into the dramatic changes in respiration. This leads the biochemical reactions including conversion of complex food material i.e. starch into simple substances like sugars. $\mathrm{Fe}$ is associated with the development flavo-proteins. Besides, $\mathrm{Zn}$ helps in other enzymatic reactions like transformation of carbohydrates, activity of hexokinase and formation of cellulose and change in sugar are considered due to its action on zymohexose (Dutta and Dhua, 2002).

\section{Conclusion}

On the basis of experimental findings it can be concluded that external foliar application of micronutrients viz. $\mathrm{Zn}, \mathrm{Fe}$ and $\mathrm{B}$ either singly or in combination produced the vital effect on various fruit parameters. But various growth parameters were remain uninfluenced after foliar application of micronutrients singly or in combinations. The application of $0.5 \% \mathrm{ZnSO}_{4}+0.5 \% \mathrm{FeSO}_{4}+0.3 \%$ Borax has recorded for higher yield, number of fruit per shoot. The application of $0.5 \% \mathrm{ZnSO}_{4}+0.3 \%$ Borax reported minimum fruit drop per shoot and fruit drop per cent. The sensory evaluation in terms of aroma, taste, flavour, texture and overall acceptability was recorded better with application of $0.5 \% \mathrm{ZnSO}_{4}+$ $0.5 \% \mathrm{FeSO}_{4}$.

\section{REFERENCES}

Afria, B.S.; Pareek, C.S.; Garg, D.K. and Singh, K. (1999).
Effect of foliar spray of micronutrients and their combinations on yield of Pomegranate. Annals of Arid Zone, 38(2):189-190.

Anonymous (2013). http://www.cropnutrition.com/efumicronutrients\#overview

Bhambota, J.R.; Azad, K.C.; Kanwar, J.S. and Dhingra, D.R. (1962).Study of the effect of sprays with micronutrients of the chlorosis of citrus.Hort. Adv., $6: 168-172$.

Dutta, P. and Dhua, R.S. (2002).Improvement on fruit quality of Himsagar mango through application of zinc, iron and manganese.Hort. J., 15(2): 1 - 9.

Keram K.S., Sharma B.L., Kewat M.L. and Sharma G.D. (2014).Effect of zinc fertilization on growth, yield and quality of wheat grown under agro-climatic condition of kymore plateau of madhyapradesh, India. The BioScan. 9 (4) : 1479-1483.

Kumar, S. and Shukla, A.K. (2010). Improvement of old ber orchard through bunding and micronutrients management.Indian J. of Hort.,67(3):322-327.

Panse, V.G. and Sukhatme, P.V. (1985) .Statistical methods for Agricultural workers. ICAR Pub., New Delhi.

Ram, R.A. and Bose, T.K. (2000). Effect of foliar application of magnesium and micronutrients on growth, yield and fruit quality of mandarin orange. Indian J. Hort., 57 (3):215-220.

Ranganna, S. (2000). "Hand book of Analysis and Quality Control for Fruit and Vegetable Productions" Tata McGraw Hill publishing company limited, New Delhi.

Sarolia, D.K.; Rathore, N.S. and Rathore, R.S. (2007). Response of zinc sulphate and iron sulphate sprays on growth and productivity of guava cv. Sardar. Curr. Agric., 31(1-2):73-77..

Yadav, V., Singh, P.N. and Yadav, P. (2013). Effect of foliar fertilization of boron, zinc and ironon fruit growth and yield of low-chill peach cv. Sharbati. International Journal of Scientific and Research Publications. 8(3) : 1 -6 . 